\title{
Submitral left ventricular aneurysm: The location of the circumflex coronary artery in relation to the aneurysm influences the surgical approach and outcome
}

\author{
Sathyaki Purushotham, MS, ${ }^{a}$ Soman Rema Krishna Manohar, MCh, ${ }^{a}$ \\ Sivasankaran Sivasubramaniam, $\mathrm{DM}^{\mathrm{b}}$ and \\ Kurur Sankaran Neelakandhan, MCh, ${ }^{a}$ Kerala, India
}

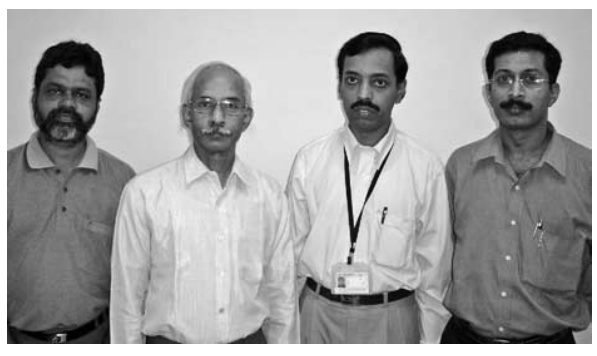

Manohar, Neelakandhan, Sivasankaran, Sathyaki (left to right)

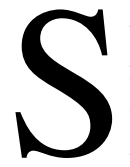

ubmitral left ventricular aneurysms are rare forms of nonischemic aneurysm thought to be developmental in origin. Originally described in young male subjects of African ancestry, ${ }^{1}$ they occur in relation to the posterior mitral annulus, producing valve incompetence and left ventricular dysfunction. The widespread availability of echocardiography in recent years has made preoperative diagnosis possible. ${ }^{2}$ We focus on our experience with the surgical correction of this uncommon entity.

\section{Patients and Methods}

Demographic and preoperative variables are summarized in Table 1.

Echocardiographic diagnosis of submitral aneurysm was made in all patients. Coronary angiograms in 3 patients showed a splayed and displaced circumflex coronary artery.

Operative technique. Table 1 summarizes the operative approach and outcome. Standard aortic and bicaval cannulation was used for cardiopulmonary bypass in 6 patients. Femoral cannulation was used for bypass in 2 patients who underwent thoracotomy.

In 5 patients we approached the aneurysm through the left atrium after incising the floor. ${ }^{3}$ Unfortunately, the aneurysm did not extend superiorly and hence remained inaccessible. In 3 patients we attempted to access the neck after complete mitral valve excision, this despite the fact that the valves were relatively normal. The valves unfortunately required replacement. The aneurysm was repaired in 2 patients but could not be accomplished in 1 patient, despite valve excision, and the valve alone was replaced. In the fifth and sixth patients the aneurysm remained inaccessible from the left atrial floor and hence was approached externally and repaired.

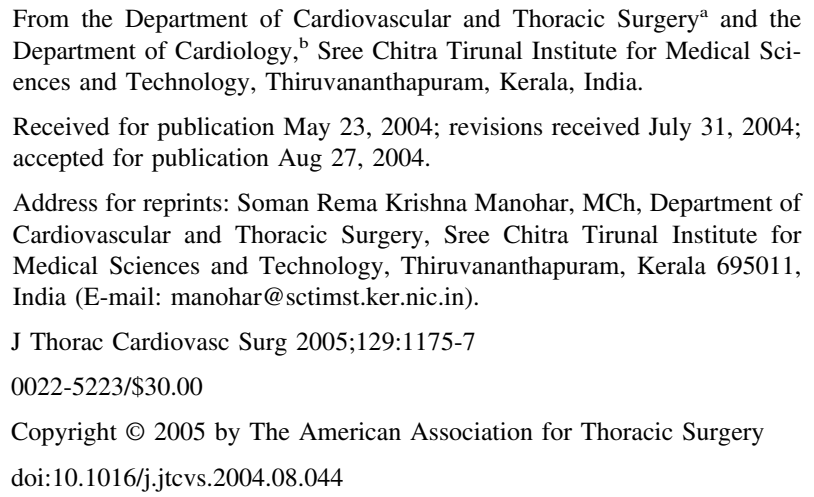

We approached the aneurysm through a thoracotomy in 2 patients. The first had mild mitral regurgitation, the aneurysm was approached easily, and the mouth was closed directly. The circumflex coronary artery seen coursing along the superior margin of the aneurysmal neck could easily be protected. The second patient had severe mitral regurgitation. The aneurysm originated from the posterior left ventricular wall in relation to the crux and lay on either side of the circumflex coronary. Although the vessel was easily visualized, we did not repair the part of the aneurysm lying superior to the circumflex coronary artery to avoid sacrificing this artery in a young patient.

Outcome. Three patients are undergoing long-term follow up. The first, followed for 15 years, has remained asymptomatic. The 2 remaining patients underwent aneurysm repair through a thoracotomy. Of these, one remains asymptomatic over the last 7 years with mild mitral regurgitation, and the other, in whom a combined approach was used, has been asymptomatic for 3 years with a small residual aneurysm.

\section{Discussion}

Submitral left ventricular aneurysms are usually found singly in the submitral position. The circumflex coronary artery generally lies in relation to the posteroinferior aspect of its neck (Figure 1, A). Coronary artery compression can occur and contributes to left ventricular dysfunction. The direction of growth is variable ${ }^{4}$ but occurs predominantly behind the left atrium. Factors that dictate this are largely unknown, but the atrioventricular valve and the circumflex coronary artery probably make a good guide.

It is possible that the aneurysm takes a superior direction to lie behind the left atrium when the mouth lies superior to the circumflex coronary artery, whereas its location below forces it to extend inferiorly behind the left ventricle (Figure 1).

Coronary angiograms with left ventricular injections can demonstrate the relation of the aneurysm to the circumflex coronary artery and the direction of its growth (Figure 2). In our patients the aneurysm extended posteroinferiorly, with the circumflex coronary artery lying in relation to the superior aspect of its neck in all (Figure 1,B). Although this appears to be only a minor variation, it has a major influence on surgical approach. The left atrial approach in this setting would not only be unsuccessful in providing access to the neck, but this could also jeopardize the circumflex coronary artery if attempted. In those in whom this approach was attempted, we accessed the neck with difficulty and after mitral valve excision. This presentation could also explain the less common mitral involvement. In aneurysms enlarging superiorly above 

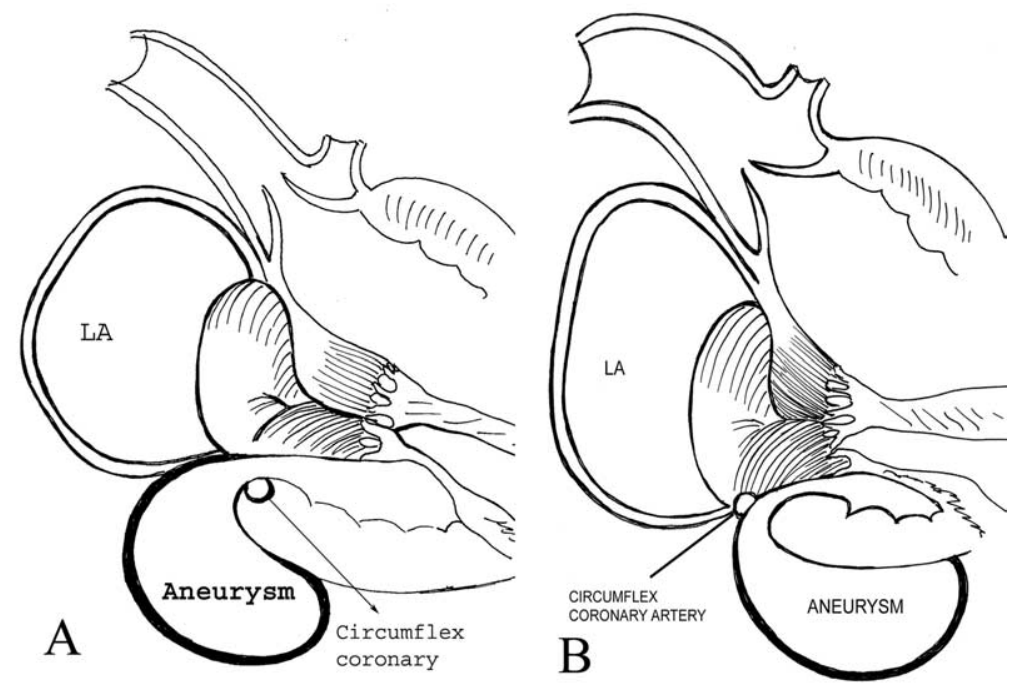

Figure 1. A, Relationship of the aneurysm to the posterior mitral annulus, the left atrium, and the circumflex coronary artery. Note that when the aneurysmal neck lies superior to the circumflex coronary artery, it is in contact with the floor of the left atrium. The left atrial approach is ideal in this situation. B, The circumflex coronary in relation to the superior aspect of the aneurysmal neck. In this situation the aneurysm is unrelated to the floor of the left atrium, which makes the left atrial approach less suitable. $L A$, Left atrium.

TABLE 1. Demographic and preoperative variables

\begin{tabular}{|c|c|c|c|c|c|c|c|c|}
\hline $\begin{array}{l}\text { Patient } \\
\text { no. }\end{array}$ & Age/sex & $\begin{array}{l}\text { NYHA } \\
\text { class }\end{array}$ & MR & Surgical approach & Repair technique & MVR & $\begin{array}{c}\text { Initial } \\
\text { outcome }\end{array}$ & Late outcome \\
\hline 1 & $35 / F$ & II & + & Sternotomy & $\begin{array}{l}\text { Excision, direct } \\
\text { repair }\end{array}$ & No & Survived & $\begin{array}{l}\text { FU: } 15 \mathrm{y} ; \\
\text { asymptomatic, } \\
\text { grade } 3 \mathrm{MR}\end{array}$ \\
\hline 2 & $21 / \mathrm{F}$ & I & + & Sternotomy & $\begin{array}{l}\text { Transmitral, } \\
\text { direct repair }\end{array}$ & Yes & $\begin{array}{l}\text { Survived, } \\
\text { residual } \\
\text { aneurysm }\end{array}$ & Lost to FU \\
\hline 3 & $38 / \mathrm{M}$ & II & ++ & Sternotomy & $\begin{array}{l}\text { Transmitral, not } \\
\text { accessible }\end{array}$ & Yes & $\begin{array}{l}\text { Survived, } \\
\text { not } \\
\text { improved }\end{array}$ & $\begin{array}{l}\text { Reoperated } \\
\text { elsewhere } \\
\text { after } 2 \mathrm{y} \text {, died }\end{array}$ \\
\hline 4 & $38 / F$ & I & ++ & Sternotomy & $\begin{array}{l}\text { Transmitral patch } \\
\text { repair }\end{array}$ & Yes & $\begin{array}{l}\text { Survived, } \\
\text { residual } \\
\text { aneurysm }\end{array}$ & $\begin{array}{c}\text { Died after } 4 \mathrm{y}, \\
\text { progressive LV } \\
\text { dysfunction }\end{array}$ \\
\hline 5 & $25 / F$ & IV & ++++ & Sternotomy & $\begin{array}{c}\text { Transaneurysmal } \\
\text { patch repair }\end{array}$ & Yes & $\begin{array}{l}\text { Failed to } \\
\text { come } \\
\text { off } \\
\text { bypass }\end{array}$ & \\
\hline 6 & $33 / F$ & II & ++ & Sternotomy & $\begin{array}{c}\text { Trans-LV, Dacron } \\
\text { patch repair }\end{array}$ & & $\begin{array}{l}\text { LCO, } \\
\text { died }\end{array}$ & \\
\hline 7 & $26 / \mathrm{M}$ & II & - & $\begin{array}{l}\text { Left thoracotomy, } \\
\text { femorofemoral } \\
\text { bypass }\end{array}$ & $\begin{array}{c}\text { Transanuerysmal } \\
\text { patch repair }\end{array}$ & No & Survived & $\begin{array}{l}\text { 7-y FU restudy: } \\
\text { good result, } \\
\text { mild MR }\end{array}$ \\
\hline 8 & $23 / \mathrm{M}$ & IV & ++++ & $\begin{array}{l}\text { Left thoracotomy } \\
+ \text { sternotomy, } \\
\text { femoral bypass }\end{array}$ & $\begin{array}{c}\text { Transaneurysmal } \\
\text { patch repair }\end{array}$ & Yes & Survived & $\begin{array}{l}\text { 2-y FU, } \\
\text { asymptomatic } \\
\text { restudy: small } \\
\text { residual } \\
\text { aneurysm+ }\end{array}$ \\
\hline
\end{tabular}




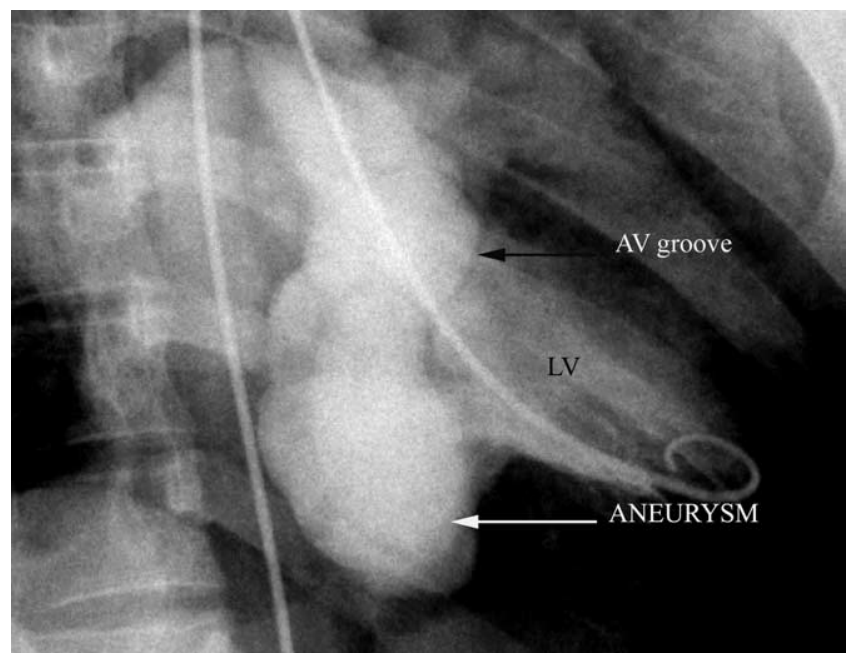

Figure 2. Left ventricular angiogram of the relationship of the atrioventricular groove to the aneurysm: white arrow, aneurysm; black arrow, atrioventricular groove. AV groove, Atrioventricular groove; $L V$, left ventricle. the circumflex, a transatrial approach would no doubt be ideal. In cases similar to ours, a direct approach through a left thoracotomy is a good alternative because the circumflex artery can be clearly visualized and protected. Moreover, most patients do not have significant mitral regurgitation and might not require an additional mitral valve procedure

Our approach, which is based on the relationship of the circumflex coronary artery to the neck of the aneurysm as demonstrated on a preoperative angiogram, appears to be safe and will result in significant reduction in mortality and morbidity in managing this rare and difficult condition, particularly in parts of the world outside Africa.

\section{References}

1. Abrahams DG, Barton CJ, Cockshott WP, et al. Annular subvalvular left ventricular aneurysms. $Q$ J Med. 1962;31:345-60.

2. Cockshott WP, Antia A, Ikeme A, Uzodike VO. Annular subvalvar left ventricular aneurysms. Br J Radiol. 1967;40:424-35.

3. Antunes MJ. Submitral left ventricular aneurysms: correction by a new transatrial approach. J Thorac Cardiovasc Surg. 1987;94:241-5.

4. Wolpowitz A, Arman B, Barnard M, Barnard C. Annular subvalvar idiopathic left ventricular aneurysms in the black African. Ann Thorac Surg. 1979;27:350-4.

\section{Sternal resection and reconstruction after renal cell carcinoma metastatic to the sternum}

Jeremy W. Pyle, BS, ${ }^{a}$ Jennifer L. Ash, MD, ${ }^{b}$ Syed M. Hussain, MD, ${ }^{b}$ Nicole Reid, MD, and Richard C. Anderson, MD, ${ }^{b, c}$ Peoria, III

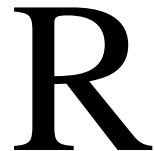

enal cell carcinoma is neither uncommon nor easy to detect. For this reason, coupled with the highly vascular nature of this tumor, it is frequently discovered incidentally or through workup of a metastasis. Literature from $1972^{1}$ and $1981^{2}$ detail 3 patients who underwent both nephrectomy and sternal resection for a metastatic renal cell carcinoma and were asymptomatic after 5 years. Since that time,

\footnotetext{
From the University of Illinois College of Medicine at Peoria, ${ }^{a}$ Department of Surgery $^{\mathrm{b}}$ and Section of Cardiothoracic Surgery, ${ }^{\mathrm{c}}$ Peoria, Ill.

Received for publication July 22, 2004; accepted for publication Aug 23, 2004.

Address for reprints: Richard C. Anderson, MD, FACS, University of Illinois College of Medicine at Peoria, Department of Surgery, North Building, 2nd Floor, 624 NE Glen Oak Ave, Peoria, IL 61603-3135.

J Thorac Cardiovasc Surg 2005;129:1177-8

$0022-5223 / \$ 30.00$

Copyright $\odot 2005$ by The American Association for Thoracic Surgery doi:10.1016/j.jtcvs.2004.08.050
}

written material on the topic of isolated renal cell metastases has been sparse. Given the current state of prosthetic materials and surgical expertise, in the presence of an isolated metastatic lesion to the sternum, resection and reconstruction with intent to palliate or obviate disease is preferred. We report on our experience with one case of a singular metastatic focus in the sternum and the sternectomy and reconstruction used in treatment.

\section{Clinical Summary}

A 47-year-old woman had pain overlying the sternum. Clinical examination at that time showed a tender protuberance with fullness across the manubrium and proximal sternum. Computed tomography of the chest and abdomen was obtained and revealed a $2.2 \times 4.5-\mathrm{cm}$ sternal mass (Figures 1 and 2) and a $5.8 \times 6.4-\mathrm{cm}$ left renal hilar mass invading the left renal vein. A subsequent positron emission tomographic scan showed hypermetabolism in the kidney and sternum. Biopsy of the sternal mass was performed, and pathology revealed metastatic renal cell carcinoma. Given that she showed no overt or radiologic signs of other lesions, the patient underwent left nephrectomy and was prepared for sternal resection and reconstruction. 